$1-1-2009$

\title{
Gonzales, Casey and the Viability Rule
}

Randy Beck

University of Georgia School of Law, rbeck@uga.edu

Depress

\section{Repository Citation}

Randy Beck, Gonzales, Casey and the Viability Rule (2009),

Available at: https://digitalcommons.law.uga.edu/fac_artchop/699

This Article is brought to you for free and open access by the Faculty Scholarship at Digital Commons @ University of Georgia School of Law. It has been accepted for inclusion in Scholarly Works by an authorized administrator of Digital Commons @ University of Georgia School of Law. Please share how you have benefited from this access For more information, please contact tstriepe@uga.edu. 


\section{Essays}

\section{GONZALES, CASEY, AND THE VIABILITY RULE}

Randy Beck

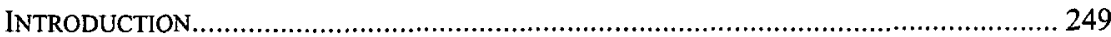

1. WHY EXPECT A RATIONALE FOR THE VIABILITY RULE? ....................................... 253

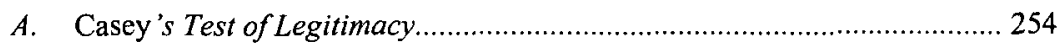

B. The Moral Randomness of the Viability Standard..................................... 257

C. Viability in International Perspective ...................................................... 261

II. The SUPREME CoURT'S FaILURE To JUSTIFY THE VIABILITY RULE ...................... 267

A. The Missing Syllogism of Roe v. Wade ................................................ 268

B. The Ambiguous and Conclusory Syllogism of Planned Parenthood v.

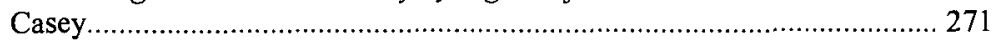

C. Justifying the Viability Rule After Gonzales v. Carhart..............................2276

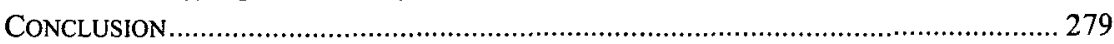

\section{INTRODUCTION}

For more than a third of a century, United States courts have vigorously applied a seemingly arbitrary rule, one never justified in either legal or moral terms. Since Roe v. Wade, the Supreme Court has maintained that the right to abortion continues until fetal "viability," the point at which the fetus is "potentially able to live outside the mother's womb, albeit with artificial aid." This Essay questions the constitutional justification for the viability rule, particularly in light of the Court's recent decision in Gonzales v. Carhart. $^{2}$

The concept of viability first entered the Supreme Court's abortion jurisprudence as an element of Roe's now-abandoned "trimester framework," which evaluated abortion regulations based on the stage of pregnancy to which they applied. ${ }^{3}$ Roe concluded that the state interest in protecting fetal

* Associate Professor, University of Georgia School of Law, I would like to express my appreciation to Helen Alvare, Christian Cotton, Raymond Marcin, Bryan McGraw, Michael Scaperlanda, and Judson Shelnutt, all of whom provided comments on a draft of this Essay. They are not responsible for any errors that remain.

1410 U.S. $113,160(1973)$.

2127 S. Ct. 1610 (2007).

3 Planned Parenthood of Se. Pa. v. Casey, 505 U.S. 833, 872 (1992) (O'Connor, Kennedy and Souter, JJ., plurality opinion); see also Nancy K. Rhoden, Trimesters and Technology: Revamping Roe v. Wade, 95 YALE L.J. 639, 640 (1986) ("[T]wo medically determined times-the time when the haz- 
life becomes "compelling"-justifying substantial regulation or proscription of abortion - only at viability, ${ }^{4}$ a period then identified with the third trimester of pregnancy. ${ }^{5}$ This viability rule generated dissents in subsequent cases from Justices who considered the Court's line "arbitrary." Justice White, for example, maintained that "the possibility of fetal survival is contingent on the state of medical practice and technology, factors that are in essence morally and constitutionally irrelevant."7

Nearly two decades after Roe, the controlling opinion in Planned Parenthood of Southeastern Pennsylvania v. Casey discarded the "rigid" trimester framework and substituted a more accommodating "undue burden" standard. ${ }^{8}$ The plurality, however, retained the rule that a state may not prohibit abortion prior to fetal viability, ${ }^{9}$ though with the recognition that medical advances had pushed viability to an earlier point in pregnancy than at the time of Roe..$^{10}$ Justice Scalia labeled the plurality's defense of the vi-

ards of abortion surpassed those of childbirth, and the time of fetal viability-appeared to form the structural foundation of the Roe trimester framework.").

${ }^{4}$ Roe, 410 U.S. at 163-64 ("With respect to the State's important and legitimate interest in potential life, the 'compelling' point is at viability. ... If the State is interested in protecting fetal life after viability, it may go so far as to proscribe abortion during that period, except when it is necessary to preserve the life or health of the mother.").

${ }^{5}$ Casey, 505 U.S. at 872 (plurality opinion) (under Roe's trimester framework, "during the third trimester, when the fetus is viable, prohibitions are permitted provided the life or health of the mother is not at stake").

${ }^{6}$ See, e.g., Thomburgh v. Am. Coll. of Obstetricians and Gynecologists, 476 U.S. 747, 794 (1986) (White, J., dissenting) ("[T]he Court's choice of viability as the point at which the State's interest becomes compelling is entirely arbitrary."); Akron v. Akron Ctr. for Reprod. Health, Inc., 462 U.S. 416, 461 (1983) (O'Connor, J., dissenting) ("The choice of viability as the point at which the state interest in potential life becomes compelling is no less arbitrary than choosing any point before viability or any point afterward."). Actually, Justice Blackmun had already acknowledged the potential arbitrariness of treating viability as the controlling line in an internal memorandum circulated with an early draft of Roe v. Wade. See DAVID GarRow, LiBERTY AND SEXUALITY 580 (1998) (quoting cover memorandum from Harry Blackmun accompanying draft of Roe v. Wade (Nov. 22, 1972) (on file with the Library of Congress)) ("You will observe that I have concluded that the end of the first trimester is critical. This is arbitrary, but perhaps any other selected point, such as quickening or viability, is equally arbitrary."); Randy Beck, The Essential Holding of Casey: Rethinking Viability, 75 UMKC L. REV. 713, 722-23 (2007).

${ }^{7}$ Thornburgh, 476 U.S. at 795 (White, J., dissenting).

8 Casey, 505 U.S. at 879.

${ }^{9}$ Id. at 879 . I have argued elsewhere that none of the issues in Casey turned on the stage of fetal development since the regulations in question applied throughout pregnancy. Consequently, the plurality's retention of the viability rule can be viewed as dicta. See Beck, supra note 6, at 715-19.

${ }^{10}$ Casey, 505 U.S. at 860 ("We have seen how time has overtaken some of Roe's factual assumptions: advances in maternal health care allow for abortions safe to the mother later in pregnancy than was true in 1973, and advances in neonatal care have advanced viability to a point somewhat earlier. . . The soundness or unsoundness of [the constitutional judgment that viability is the earliest point at which states may ban nontherapeutic abortions] in no sense turns on whether viability occurs at approximately 28 weeks, as was usual at the time of Roe, at 23 to 24 weeks, as it sometimes does today, or at some moment even slightly earlier in pregnancy, as it may if fetal respiratory capacity can somehow be en- 
ability rule "conclusory," highlighting an earlier opinion in which the plurality's Justice O'Connor had criticized viability as an arbitrary line. ."

The viability rule once again emerged as a point of contention (though on different grounds) in Gonzales, the Court's most recent decision addressing the scope of abortion rights. ${ }^{12}$ The narrowly divided Gonzales Court rejected a facial challenge to the federal Partial-Birth Abortion Ban Act of $2003 .^{13}$ While the majority assumed the applicability of the viability rule, ${ }^{14}$ it upheld a federal ban on the "intact dilation and evacuation" ("intact D\&E") procedure that applied without regard to the stage of fetal development. ${ }^{15}$ Justice Kennedy explained that "[t]he Act does apply both previability and postviability because, by common understanding and scientific terminology, a fetus is a living organism while within the womb, whether or not it is viable outside the womb."16 In dissent, Justice Ginsburg twice accused the majority of "blur[ring] the line, firmly drawn in Casey, between previability and postviability abortions."

The continuing discord over viability reflected in Gonzales highlights an issue that remains unsettled thirty-six years after Roe: Why a state may protect the life of a fetus after it reaches viability, but not before. The Court has yet to supply an adequate constitutional rationale for requiring the capacity to survive outside the womb as a necessary condition for state pro-

hanced in the future.") (citations omitted). The possibility that the point of viability would change over time was an anticipated consequence of selecting the viability line. See Planned Parenthood of Cent. Mo. v. Danforth, 428 U.S. 52, 61 (1976) (Roe's definition of viability was "purposefully left flexible for professional determination, and dependent upon developing medical skill and technical ability").

11 Casey, 505 U.S. at 989 n.5 (Scalia, J., concurring in the judgment in part and dissenting in part) ("Of course Justice O'Connor was correct in her former view. The arbitrariness of the viability line is confirmed by the Court's inability to offer any justification for it beyond the conclusory assertion that it is only at that point that the unborn child's life 'can in reason and all fairness' be thought to override the interests of the mother.") (referencing Akron, 462 U.S. at 461 (O'Connor, J., dissenting)).

12 Compare 127 S. Ct. at 1627 (noting that the Federal Partial-Birth Abortion Ban Act of 2003 banned intact dilation and evacuation procedure "both previability and postviability"), with id. at 1640 41, 1649-50 (Ginsburg, J., dissenting) (noting that Casey drew a firm line between previability and postviability abortions).

${ }^{13}$ Id. at 1639 (rejecting challenge to 18 U.S.C. $\S 1531$ ).

14 See id. at 1626 ("We assume the following principles for the purposes of this opinion. Before viability, a State "may not prohibit any woman from making the ultimate decision to terminate her pregnancy.") (quoting Casey, 505 U.S. at 879 (plurality opinion)); see also id. at 1632 ("Under the principles accepted as controlling here, the Act, as we have interpreted it, would be unconstitutional 'if its purpose or effect is to place a substantial obstacle in the path of a woman seeking an abortion before the fetus attains viability.' Casey, 505 U.S., at 878,112 S.Ct. 2791 (plurality opinion). The abortions affected by the Act's regulations take place both previability and postviability; so the quoted language and the undue burden analysis it relies upon are applicable.").

15 Id. at 1627 . The majority did note that the intact D\&E abortion method is used "in the later stages of pregnancy." Id, at 1619 .

${ }^{16}$ Id.

${ }^{17}$ Id. at 1627 (Ginsburg, J., dissenting); see also id. at 1649-50. 
tection of fetal life. Professor John Hart Ely famously criticized Roe for failing to explain "[e]xactly why that is the magic moment," observing that "the Court's defense seems to mistake a definition for a syllogism." than three and a half decades after Roe, the problem Professor Ely highlighted remains unresolved.

This Essay argues that the Supreme Court has an unmet obligation to account for the significance accorded to fetal viability in its abortion jurisprudence. Neither Roe nor Casey provided a constitutional justification for the viability rule, and Gonzales makes such a justification even harder to envision. Under the reasoning of Casey, if the Court cannot offer a principled constitutional rationale for requiring the ability to survive ex utero as a condition for state protection, then the Court should abandon the viability rule as an illegitimate and arbitrary line, inappropriate for judicial imposition.

Before examining the Court's defense of the viability rule, this Essay explores the preliminary question of whether the rationale for the rule really matters. After all, the Court has largely avoided this issue for thirty-six years. Part I offers three reasons to believe the Court has an obligation to either justify the viability rule or abandon it. First, I emphasize Casey's acknowledgement that judicial decisions can only be considered legitimate to the extent the Court provides a nonarbitrary constitutional justification for the lines it draws. ${ }^{19}$ As a majority of the Casey Court recognized, "a decision without principled justification would be no judicial act at all." 20 Second, I discuss some of the disquieting consequences of the viability rule, which causes fetal and maternal rights to vary based on legally and morally irrelevant factors, such as the state of prenatal medicine during the period of gestation, the proximity of the mother to advanced medical facilities, the outlook of the doctor making the viability assessment, and the race and gender of the fetus. ${ }^{21}$ If the Court wants to tie constitutional status to a biological criterion that generates morally random outcomes, it should offer a principled basis for the rule that produces these results. Third, I sketch out the practical import of the viability rule, which prevents state regulation of late-term abortions that would be illegal in all but a handful of other countries. ${ }^{22}$ Viewed from an international perspective, selection of a rule near the extreme end of available options creates the appearance that the Court made a social or political decision, an impression that can be dispelled only

\footnotetext{
18 John Hart Ely, The Wages of Crying Wolf: A Comment on Roe v. Wade, 82 YALE L.J. 920, 924

19 See infra notes 31-47 and accompanying text.

20 Planned Parenthood of Se. Pa. v. Casey, 505 U.S. 833, 865 (1992).

21 See infra notes $48-71$ and accompanying text.

22 See infra notes 72-98 and accompanying text.
} (1973). 
by providing a convincing rationale for the viability rule grounded in neutral constitutional principles.

Part II of the Essay examines the weakness of the Supreme Court's defense of the viability line. The discussion begins with the broad academic consensus that Roe failed to offer any argument in favor of the viability rule. ${ }^{23}$ Missing from the Court's "syllogism" in Roe was the major premise- a constitutional analysis of state power and fetal entitlement that, when combined with the Court's definition of viability, would lead to the conclusion that the state can only protect a viable fetus.

The discussion next moves to Casey, which clarified the Court's reasoning only slightly. ${ }^{24}$ The plurality opinion in Casey described viability as marking "the independent existence of [a] second life" that "can in reason and all fairness be the object of state protection," notwithstanding the competing claims of the mother. ${ }^{25}$ The ambiguity of this passage aside, a generous reading might disclose the major premise for a syllogism supporting the viability rule. However, the plurality merely asserts its premise without defending it. Like the Court in Roe, the Casey plurality offered no theory of state power or fetal entitlement to explain why "independent existence"-or more precisely the particular form of hypothetical independence denoted by the term "viability"-constitutes a necessary condition for protection by the state. Nothing in Casey sought to link such an "independent existence" requirement to any principle drawn from the Constitution. The viability rule therefore fails the test of judicial legitimacy the Court itself set forth in $\mathrm{Ca}$ sey.

Part II concludes by showing that the Gonzales decision undermines Casey's attempted defense of the viability rule. ${ }^{26}$ The Court in Gonzales recognized that a previable fetus represents a second life with an existence independent of the mother. The Gonzales opinion, moreover, upheld certain legal protections for the previable fetus based in part on its similarity to a newborn infant. The reasoning of Gonzales therefore makes it even more difficult to articulate and support a constitutional justification for the viability rule along the lines intimated in Casey.

\section{WHY EXPECT A RATIONALE FOR THE VIABILITY RULE?}

From 1973 to the present, United States courts have consistently struck down every law perceived to create a substantial obstacle to the abortion of any fetus that had not crossed the viability threshold, regardless of the rea-

\footnotetext{
23 See infra notes 108-125 and accompanying text.

24 See infra notes 126-148 and accompanying text.

${ }^{25}$ Casey, 505 U.S. at 870 (plurality opinion).

26 See infra notes 149-171 and accompanying text.
} 
sons for wanting an abortion. ${ }^{27}$ In all that time, the Supreme Court has never explained how it might derive this viability rule from the Constitution. Even if one assumes that the Constitution protects a right to terminate a pregnancy, the Court has never offered a principled explanation for its conclusion that the right endures until the fetus can survive outside the womb. ${ }^{28}$

The Court owes the public a principled justification for treating viability as the dispositive constitutional line. Section A of this Part discusses the test of legitimacy Casey invited the public to apply when evaluating the Court's decisions. ${ }^{29}$ Sections $B$ and $C$ argue that certain ramifications of the viability rule call for explanation: its moral randomness and its wide departure from the international mainstream with respect to the duration of abortion rights. ${ }^{30}$

\section{A. Casey's Test of Legitimacy}

This Essay asks the Supreme Court to provide a principled explanation for the viability rule, an obligation the Court already acknowledged in the Casey opinion. Casey placed great weight on judicial "legitimacy" as a necessary foundation for the beneficial exercise of judicial power. ${ }^{31}$ In a portion of the joint opinion joined by a majority of the Court, the Justices noted that judges cannot expend funds to obtain support for their decisions and have only limited ability to coerce obedience. ${ }^{32}$ The Supreme Court's effectiveness in fulfilling its constitutional responsibilities therefore turns on public assessment of the "legitimacy" of its decisions, "a product of substance and perception that shows itself in the people's acceptance of the Judiciary as fit to determine what the Nation's law means and to declare what it demands." ${ }^{33}$ Failure to maintain the Court's legitimacy, the majority believed, would threaten our collective ability to view ourselves as a country committed to the rule of law. ${ }^{34}$

\footnotetext{
${ }^{27}$ See, e.g., Stenberg v. Carhart, 530 U.S. 914, 930 (2000) (striking down the Nebraska partial birth abortion ban, which applied before and after viability); Casey, 505 U.S. at 893-94 (spousal notification requirement, which applied prior to viability, invalidated as a substantial obstacle to abortion); Planned Parenthood Ass'n of Kan. City v. Ashcroft, 462 U.S. 476, 481-82 (1983) (requirement that second trimester abortions be performed in a hospital unreasonably infringed on abortion rights); Colautti $v$. Franklin, 439 U.S. 379, 389-94 (1979) (striking down an act imposing a standard of care in the performance of an abortion where the fetus "may be viable").

28 See infra notes 108-148 and accompanying text.

29 See infra notes 31-47 and accompanying text.

30 See infra notes 48-98 and accompanying text

31 Casey, 505 U.S. at 864-69.

$32 \mathrm{Id}$. at 865 .

${ }^{33}$ Id.

34 Id. at 868 ("Like the character of an individual, the legitimacy of the Court must be earned over time. So, indeed, must be the character of a Nation of people who aspire to live according to the rule of
} 
Much of Casey's discussion of legitimacy related to concerns about public perception of a decision overruling Roe v. Wade. ${ }^{35}$ However, the majority also wrote at length about the Court's obligation to act on principled grounds so that its opinions merit recognition as legitimate. The Justices acknowledged that "[t]he underlying substance of this legitimacy is of course the warrant for the Court's decisions in the Constitution and the lesser sources of legal principle on which the Court draws." 36 Consequently, "a decision without principled justification would be no judicial act at all." ${ }^{37}$

While acting on principled grounds constitutes an indispensable foundation, the Casey Court also indicated that judicial legitimacy requires something more. ${ }^{38}$ The Court must present the principles underlying its decisions for inspection by the public:

Because not every conscientious claim of principled justification will be accepted as such, the justification claimed must be beyond dispute. The Court must take care to speak and act in ways that allow people to accept its decisions on the terms the Court claims for them, as grounded truly in principle, not as compromises with social and political pressures having, as such, no bearing on the principled choices that the Court is obliged to make. Thus, the Court's legitimacy depends on making legally principled decisions under circumstances in which their principled character is sufficiently plausible to be accepted by the Nation. ${ }^{39}$

Given that legitimacy constitutes "a product of substance and perception, ${ }^{\prime 40}$ the Court must act transparently in order to maintain public confidence. The public must be able to see how judicial decisions derive from constitutional principles in order to accept those decisions as legitimate. If the Court fails to explain the principles justifying a decision, the public may

law. Their belief in themselves as such a people is not readily separable from their understanding of the Court invested with the authority to decide their constitutional cases and speak before all others for their constitutional ideals. If the Court's legitimacy should be undermined, then, so would the country be in its very ability to see itself through its constitutional ideals. The Court's concern with legitimacy is not for the sake of the Court, but for the sake of the Nation to which it is responsible.").

35 Thus, the plurality expressed concern about the damage to its reputation if it was perceived to be overruling Roe v. Wade in response to political pressure. See id. at 867 ("So to overrule under fire in the absence of the most compelling reason to reexamine a watershed decision would subvert the Court's legitimacy beyond any serious question.").

${ }^{36} I d$. at 865 .

${ }^{37}$ Id.

38 Id. ("But even when justification is furnished by apposite legal principle, something more is required.").

39 Id. at $865-66$.

$40 I d$. at 865 ; see also id. at 866 (referring to "[t] he need for principled action to be perceived as such"). 
suppose that the outcome represents an unprincipled compromise produced by social or political pressures.

Casey addressed the viability rule in a later portion of the opinion reflecting the views of Justices O'Connor, Kennedy and Souter. ${ }^{41}$ This plurality reemphasized the Court's obligation to offer principled rationales for its decisions: "[L]egislatures may draw lines which appear arbitrary without the necessity of offering a justification. But courts may not. We must justify the lines we draw." ${ }^{42}$ As understood by the Casey plurality, then, the Court's responsibility to provide transparent and principled justifications for its rulings applies not just to the derivation of constitutional rights but also to the selection of the particular lines that implement and constrain those rights. The viability rule therefore requires a principled justification.

The Casey opinion thus offers a test of judicial legitimacy by which to evaluate the Court's defense of the viability rule. The Court must show that viability is not simply an arbitrary line reflecting some Justices' views of a reasonable social or political compromise in the area of abortion rights. The Court must instead provide a principled analysis demonstrating the warrant for the viability rule in the Constitution. This principled justification must be apparent to readers of the Court's opinions and "sufficiently plausible to be accepted by the Nation." must tailor its decisions to accommodate public opinion, but rather that its decisions should plausibly demonstrate that the Court is in fact interpreting the Constitution, rather than pursuing a social or political agenda.

For many Americans, the legitimacy of the Court's jurisprudence is nowhere more in doubt than in the context of abortion rights. ${ }^{44}$ The Casey plurality recognized the "intensely divisive" nature of the abortion controversy and displayed a desire to foster some degree of consensus on the issue. ${ }^{45}$ However, if the Court asks citizens to lay aside deeply held political and social views in light of "a common mandate rooted in the Constitution," 46 it is crucial to demonstrate that constitutional mandate to the contending parties. Drawing a line as far-reaching and consequential as the

${ }^{41}$ Id. at $869-71$.

42 Id. at 870 .

${ }^{43}$ Id. at $865-66$.

44 See, e.g., Ely, supra note 18, at 947 ("[Roe is] a very bad decision. . . . It is bad because it is bad constitutional law, or rather because it is not constitutional law and gives almost no sense of an obligation to try to be."); Michael Stokes Paulsen, The Worst Constitutional Decision of All Time, 78 NOTRE DAME L. REV. 995, 999-1001 (2003).

${ }^{45}$ Casey, 505 U.S. at 866-67 (plurality opinion).

46 Id. ("Where, in the performance of its judicial duties, the Court decides a case in such a way as to resolve the sort of intensely divisive controversy reflected in Roe and those rare, comparable cases, its decision has a dimension that the resolution of the normal case does not carry. It is the dimension present whenever the Court's interpretation of the Constitution calls the contending sides of a national controversy to end their national division by accepting a common mandate rooted in the Constitution."). 
viability rule without a convincing constitutional rationale is more likely to aggravate the national division over abortion than to quell it. After all, the viability rule carves out a large territory in which the normal processes for mediating political disputes are rendered inoperative. ${ }^{47}$

\section{B. The Moral Randomness of the Viability Standard}

The viability rule that the Court debuted in Roe did not originate as a legal standard. Indeed, Justice Blackmun borrowed the concept of viability from the medical community. ${ }^{48}$ Doctors making treatment decisions with respect to preterm fetuses must predict the likely consequences of premature delivery. ${ }^{49}$ Medical researchers assist this predictive exercise by gathering information on the survival of infants delivered prior to full term. ${ }^{50}$ In recent decades, advances in care before and after birth have permitted larger percentages of preterm infants to survive at progressively earlier points in gestation. $^{51}$ The Casey plurality recognized, therefore, that the viability

47 See Mary ANn Glendon, Abortion and DivorCe IN WESTERn LAW 25 (1987) ("Nowhere have the courts gone so far as has the United States Supreme Court in precluding further statutory development [of abortion policy.]"); William N. Eskridge, Jr., Pluralism and Distrust: How Courts Can Support Democracy by Lowering the Stakes of Politics, 114 YALE L.J. 1279, 1312-13 (2005) (suggesting Roe's "very broad libertarian rule" threatened democracy and "radicalized many traditionalists," an effect moderated by Casey).

48 Roe v. Wade, 410 U.S. 113, 160 (1973) ("As we have noted, the common law found greater significance in quickening. Physicians and their scientific colleagues have regarded that event with less interest and have tended to focus either upon conception, upon live birth, or upon the interim point at which the fetus becomes 'viable,' that is, potentially able to live outside the mother's womb, albeit with artificial aid.").

${ }^{49}$ E. Gary CUNNINGHAM ET AL., Williams OBSTETRICS 857 (22d ed. 2005) (“Approaches to preterm labor and delivery currently are guided in large part by expectations for survival of the neonate.").

50 Rhoden, supra note 3, at 676 ("[M]edical statistics can show that 15,30 or 50 percent of fetuses born at a particular gestational age survive ....").

51 Jay D. Iams, Preterm Birth, in STeven G. GabBe ET AL., OBSTETRICS: NoRMAL AND PROBLEM PREGNANCIES 755, 812 (4th ed. 2002) ("As neonatal and perinatal care has improved, the lower limit of 'viability' has been a progressively earlier gestational age. Regionalized perinatal care, broader use of antenatal corticosteroids, and advances in neonatal care (e.g., surfactant treatment) have led to steady improvements in perinatal, neonatal, and infant morbidity and mortality. As many as 15 percent of infants born at 23 weeks, 56 percent at 24 weeks, and 80 percent at 25 weeks may now survive to hospital discharge in the postsurfactant era."). Particular advances have occurred with respect to respiratory capacity, a significant issue in premature deliveries:

Virtually all premature infants have respiratory problems. Treatment for such problems ideally begins before birth, with the mother being given an injection of corticosteroids, which are known to cross the placenta, and greatly accelerate lung development. After birth, respiratory problems are treated with artificial ventilation. The ventilators that are commonly used on adults have been shown to damage infant lungs, so special high frequency oscillation ventilators are commonly used. ... Used in combination with the ventilator, is surfactant replacement therapy, which has been described as "the most exciting advance in neonatal medicine of the last decade". Surfactant is a naturally occurring chemical, which helps the lungs absorb oxygen. In premature infants, there is usually insufficient surfactant in the lungs, which leads to problems in the absorption of oxygen. Surfactant replacement therapy treats this problem by supplying synthetic surfactant directly to the lung surfaces. It is believed that up to half of the decline in the US national infant 
threshold has moved several weeks closer to conception in the years since Roe. ${ }^{52}$

The change in viability statistics over time highlights one of the unfortunate consequences of using viability, a concept developed for medical purposes, as the basis for determining an individual's legal status under the Constitution. Compare a healthy 26-week-old fetus in utero in 1973 with an identical fetus similarly situated in 2009 . Under the viability rule, a state likely could not adopt abortion regulations protecting the life of such a fetus at the time of Roe but could protect an identical fetus today. ${ }^{53}$ "According to the logic of Roe $v$. Wade, then, a whole class of unborn human beings would now merit legal protection but would not have merited it then." ${ }^{14}$

This difference in legal status between the 1973 fetus and the 2009 fetus seems impossible to explain in a principled fashion. No distinction between the two fetuses justifies the disparate treatment. ${ }^{55}$ Nor is there any difference in the burden the two fetuses place on their respective mothers. ${ }^{56}$ The only change between 1973 and 2009 concerns the predicted effectiveness of medical providers in caring for the fetuses in a set of hypothetical

mortality death rate reported between 1989 and 1990 can be attributed to the introduction of sur-

factant therapy.

STEPHEN COLEMAN, THE ETHICS OF ARTIFICIAL UTERUSES: IMPLICATIONS FOR REPRODUCTION AND ABORTION 8-9 (2004) (quoting V.Y.H. Yu, Improving the Outcome of Preterm and Low Birthweight Infants 3 (1995) (unpublished manuscript)).

52 See Coleman, supra note 51, at 7 ("When Roe v. Wade was handed down, 28 weeks was commonly used as the cut off point for treatment. ... These days, things have changed so much that in the Neonatal Intensive Care Unit (NICU) of the Monash Medical Centre in Melbourne, 28 weeks is considered to be the 90-95 per cent survival point. At this NICU, the survival of babies bom at only 24 weeks gestation was routine, and the survival of babies born at only 23 weeks was not unknown. Even more surprisingly, few of these babies have significant disabilities."); supra note 10 and accompanying text.

53 Beck, supra note 6, at 730 .

54 Jeanne Heffernan Schindler, Abortion, in Medicine, Health CaRE, \& ETHICs: Catholic VOICES 117 (John F. Morris ed., 2007).

55 See Rhoden, supra note 3, at 663 ("As this brief summary shows, viability does not mark a particular biological change in the fetus. The viable fetus has no more capability for self-awareness or feeling pain than a pre-viable fetus. This conclusion follows from the fact that viability advances with medical technology, while fetal development remains the same over time."); Mark J. Beutler, Comment, Abortion and the Viability Standard-Toward a More Reasoned Determination of the State's Countervailing Interest in Protecting Prenatal Life, 21 SeTON HaLl L. Rev. 347, 363 (1991) ("The idea that the state's interest in protecting the life of a fetus at twenty-seven weeks of gestation was in some way less compelling in 1939 than in 1989 makes one suspicious of this entire inquiry. If a twenty-seven week old fetus is worth protecting at a time when science could enable its extra-uterine survival, then it is worth protecting prior to obtaining such technological capabilities. The reverse, of course, is also true.").

${ }^{56}$ Paul Benjamin Linton, Planned Parenthood v. Casey: The Flight from Reason in the Supreme Court, 13 ST. LouIS U. PUB. L. REV. 15, 68 (1993) ("[T]he viable unborn child is as physically dependent upon her mother for the same nourishment as is the unborn child who is not yet viable."). 
circumstances (premature delivery) distinct from those circumstances that in fact exist (development in utero). ${ }^{57}$

Differential treatment based on the year of conception is not the only way in which the viability rule links constitutional status to an irrelevant factor. Australian commentator Stephen Coleman suggests that changes in a woman's location during pregnancy could cause a fetus to move in and out of viability. He illustrates the point with an example:

A woman is 25 weeks pregnant, and is visiting a doctor at the Monash Medical Centre in Melbourne. Since the Monash Medical Centre has one of the most advanced Neonatal Intensive Care Units in the world, the developing human inside her would be considered viable. Now suppose that the woman leaves Melbourne, and flies to Papua New Guinea. Once she arrives in Papua New Guinea, she walks up into the highlands, where she remains until the birth. Since sophisticated medical assistance is not available in the Papua New Guinea highlands, when she arrives in the highlands her developing human would not be considered viable, and in fact would not be considered viable for almost three months. In fact, if this woman was to continue to travel regularly between Papua New Guinea and a major centre in Australia, then her unborn developing human could reach the 'point' of viability several times, becoming viable whenever she was near sophisticated medical facilities, and not viable whenever she returned to the remote Papua New Guinea highlands. ${ }^{58}$

This hypothetical "shows the problem of using viability as a moral dividing line, since viability, even more than birth, privileges location." 59

One could argue in response that the Court should base viability determinations on the best neonatal technology currently in use, even if that technology would be unavailable for a particular fetus. Justice Scalia's partial dissent in Casey understood viability to refer to "the magical second when machines currently in use (though not necessarily available to the particular woman) are able to keep an unborn child alive apart from its mother." If that is an accurate understanding of the viability rule, however, then the rule is unprincipled for a different reason: it causes the constitutional status of some fetuses to turn on unattainable hypothetical conditions, rather than real-world prospects for survival.

57 Id. at 67 ("The child's capacity to survive outside the womb is undoubtedly relevant when one is contemplating removing the child from the womb and one is concerned about the safety of the child if this is done. That capacity seems entirely irrelevant, however, when the point of viability marks only the time at which the child can no longer be removed from the womb.").

58 COLEMAN, supra note 51 , at 87.

59 Id.

60 Planned Parenthood of Se. Pa. v. Casey, 505 U.S. 833, 989 n.5 (1992) (Scalia, J., concurring in the judgment in part and dissenting in part). But see Colautti v. Franklin, 439 U.S. 379, 395-96 (1979) (the record disclosed that doctors evaluating viability consider inter alia the quality of "available" medical facilities); Linton, supra note 56 , at 40 ("[V]iability presumably depends on the availability of such technology within a particular community."). 
The constitutional relevance of viability is even more suspect when one considers that doctors sometimes reach divergent results in evaluating the survival prospects of a particular fetus. ${ }^{61}$ Since determining viability involves a prediction based on multiple factors, doctors operating in good faith may arrive at different conclusions. ${ }^{62}$ Inconsistent outcomes might flow from differences in medical skill or in the quality of equipment used in making the assessment. ${ }^{63}$ Alternatively, these differences could reflect nothing more than divergent levels of risk-aversion or conflicting treatment philosophies. $^{64}$ Interestingly, predictions about viability tend to be selffulfilling:

Several studies have reported that the expectation of the medical team of survival for the ELBW [extremely low birth weight] infant actually influences the likelihood of survival. A study of 66 infants with birth weights between 500 and $749 \mathrm{~g}$ found that after controlling for birth weight and gestational age, fetuses who were considered "viable" (i.e., likely to survive) were 18 times more likely to survive than fetuses who were deemed previable. ${ }^{65}$

Under the Court's precedents, then, the constitutional status of a particular fetus may depend on the optimism of the doctor performing the evaluation. Legal deference to disputable medical judgments becomes particularly problematic when the doctor has financial, legal, or ideological interests at stake in the determination. ${ }^{66}$

Further evidence of viability's moral and legal irrelevance lies in the fact that the race and gender of a fetus significantly influence its likelihood of survival outside the womb. Researchers have demonstrated that, gestational age and birth weight being equal, female and African American fetuses are more likely to survive premature delivery than their male and Caucasian counterparts. ${ }^{67}$ In other words, African American and female fe-

${ }^{61}$ Colautti, 439 U.S. at 396 ("In the face of these uncertainties, it is not unlikely that experts will disagree over whether a particular fetus in the second trimester has advanced to the stage of viability.").

62 Id. at 395-96 ("As the record in this case indicates, a physician determines whether or not a fetus is viable after considering a number of variables: the gestational age of the fetus, derived from the reported menstrual history of the woman; fetal weight, based on an inexact estimate of the size and condition of the uterus; the woman's general health and nutrition; the quality of the available medical facilities; and other factors. Because of the number and the imprecision of these variables, the probability of any particular fetus' obtaining meaningful life outside the womb can be determined only with difficulty.").

${ }^{63}$ Linton, supra note 56, at 41 (the accuracy of an "ultrasound determination of gestational age may depend on the quality of the machine, as well as the skill of the technician").

${ }^{64}$ See Colautti, 439 U.S. at 395-96 ("[E]ven if agreement may be reached on the probability of survival, different physicians equate viability with different probabilities of survival, and some physicians refuse to equate viability with any numerical probability at all.").

${ }^{65}$ lams, supra note 51 , at 812.

${ }^{66}$ Cf. Moore v. Regents of Univ. of Cal., 793 P.2d 479, 485 (Cal. 1990) (an informed consent case recognizing that a doctor's "personal interests . . may affect his medical judgment").

${ }^{67}$ See Beck, supra note 6, at 731. 
tuses reach the viability threshold sooner. Since viability marks the terminal point for constitutional abortion rights under Roe and Casey, the right to an abortion under the Court's precedents lasts longer for Caucasian women than for similarly situated African American women. ${ }^{68}$

No one drafting a constitution would make the status of an individual-her eligibility for protection by the state - turn on the therapeutic techniques available to address an as yet unrealized medical contingency. Nor would anyone attach controlling significance to the proximity of cutting edge medical facilities or to an "imprecise medical judgment" by a potentially self-interested physician. Likewise, one hopes that no one today would make an individual's legal status dependent on her race and gender. Why should we accept these corollaries of the viability rule, which seem inexplicable from a moral perspective?

The Judiciary adheres to clear constitutional principles, even when some of the consequences seem undesirable from a moral perspective. A person who commits a murder in one state may be subject to the death penalty, while someone who commits a much more heinous murder in a state with different laws might not face capital punishment. ${ }^{70}$ The differential treatment of the two murderers may seem unfair in the abstract. The legal system tolerates the disparity, however, as a consequence of our system of federalism, which enjoys clear constitutional support. Those who ratified the Constitution presumably knew such disparities could occur, but nevertheless preferred the advantages of decentralized power. The viability rule, however, cannot claim a grounding in the constitutional text, structure, and history, comparable to our regime of sovereign and independent states. ${ }^{71}$ If the Court cannot explain the constitutional principles that justify the viability rule, there is no reason to accept the morally random results the rule produces.

\section{Viability in International Perspective}

Comparison with other countries provides a third reason why the Supreme Court should offer a principled account of the constitutional rationale for the viability rule. Other nations terminate or constrict abortion rights at various points in pregnancy, typically at a much earlier stage in fetal devel-

\footnotetext{
${ }^{68} I d$.

69 Linton, supra note 56 , at 41 .

${ }^{70}$ Maimon Schwarzschild, Pluralism, Conversation, and Judicial Restraint, 95 Nw. U. L. REV. 961 , 972 (2001) ("There is great variation in state and local laws, reflecting different interests and values, even on matters of life and death: some states have capital punishment, for example, and others do not.").

71 See Printz v. United States, 521 U.S. 898, 918-22 (1997) (reviewing textual and historical evidence concerning the Constitution's division of power among federal and state governments).
} 
opment. $^{72}$ As Justice Scalia has noted, the Supreme Court's abortion jurisprudence "makes us one of only six countries that allow abortion on demand until the point of viability."73 Absent a convincing constitutional rationale-which neither Roe nor any subsequent decision providesselection of a rule near the extreme end of the available options gives the appearance of a political or social choice, augmenting concerns about judicial legitimacy. If the Court believes our Constitution requires not just a right to abortion, but an abortion regime significantly less protective of fetal life than most of the nations of the world, it should explain the constitutional principles compelling that conclusion.

Recent decisions by the Supreme Court have generated much discussion of when and how foreign law should affect constitutional adjudication. $^{74}$ Most controversially, the Court has cited foreign authority in deciding when the death penalty constitutes "cruel and unusual punishment" under the Eighth Amendment, ${ }^{75}$ and in determining whether particular rights are protected under a substantive due process analysis. ${ }^{76}$ These opinions have generated several arguments against the use of foreign legal authority in domestic constitutional interpretation, including concerns that

72 See CTR. FOR REPROD. RIGHTS, THE WORLD's ABORTION LAwS 2 (2008), http://www. reproductiverights.org/sites/crr.civicactions.net/files/pub_fac_abortionlaws2008.pdf; infra notes 81-93 and accompanying text.

${ }^{73}$ Roper v. Simmons, 543 U.S. 551, 625-26 (2005) (Scalia, J., dissenting) (citing Joan L. Larsen, Importing Constitutional Norms from a "Wider Civilization": Lawrence and the Rehnquist Court's Use of Foreign and International Law in Domestic Constitutional Interpretation, 65 OHIO ST. L.J. 1283, 1320 (2004) and CTR. FOR REPROD. RIGHTS, supra note 72).

${ }^{74}$ See, e.g., Daniel Bodansky, The Use of International Sources in Constitutional Opinion, 32 GA. J. INT'L \& COMP. L. 421 (2004); Steven G. Calabresi, "A Shining City on a Hill": American Exceptionalism and the Supreme Court's Practice of Relying on Foreign Law, 86 B.U. L. REV. 1335 (2006); Vicki C. Jackson, Constitutional Comparisons: Convergence, Resistance, Engagement, 119 HARV. L. REV. 109 (2005); John O. McGinnis, Foreign to Our Constitution, 100 Nw. U. L. REV. 303 (2006); Michael D. Ramsey, International Materials and Domestic Rights: Reflections on Atkins and Lawrence, 98 AM. J. INT'L L. 69 (2004); Justice Antonin Scalia, Keynote Address: Foreign Legal Authority in the Federal Courts, 98 AM. SOC'Y INT'L L. PROC. 305 (2004).

75 See, e.g., Roper, 543 U.S. at 575-78 (fact that no other country permits juvenile death penalty is not controlling, but confirms the Court's conclusion that the death penalty is disproportionate for killers younger than eighteen); Atkins v. Virginia, 536 U.S. 304, $316 \mathrm{n} .21$ (2002) ("[W]ithin the world community, the imposition of the death penalty for crimes committed by mentally retarded offenders is overwhelmingly disapproved."); Trop v. Dulles, 356 U.S. 86, 102 (1958) (plurality opinion) (citing the virtual unanimity of "civilized nations" to support the conclusion that the Eighth Amendment bars the imposition of statelessness as a punishment for crime). But see Kennedy v. Louisiana, 128 S. Ct. 2641, 2657-58 (2008) (finding a "national consensus" against the death penalty for child rape, but not analyzing foreign law).

${ }^{76}$ See, e.g., Lawrence v. Texas, 539 U.S. 558, 576-77 (2003) (noting that other nations have protected the "right of homosexual adults to engage in intimate, consensual conduct" and finding "no showing that in this country the governmental interest in circumscribing personal choice is somehow more legitimate or urgent"); Washington v. Glucksberg, 521 U.S. 702, 734-35 (1997) (experience with physician assisted suicide in Netherlands supported state claims of potential for abuse). 
selective invocation of foreign precedent gives judges too much discretion in the interpretive process, ${ }^{77}$ that reliance on foreign law undermines democratic accountability, ${ }^{78}$ and that foreign law reflects local conditions and values incompatible with unique aspects of American history, culture and government. $^{79}$

In criticizing the Court for selective reliance on foreign legal authority, Justice Scalia has more than once highlighted the Court's failure to consult international practice in the context of abortion rights. ${ }^{80}$ Comparative analysis supports his contention that, by allowing abortion for any reason until viability, the Court has pushed U.S. abortion law far outside the international mainstream. Joan Larsen points out that "the vast majority" of countries "forbid abortion after 12 weeks gestation." " Data from the Center for Reproductive Rights, an abortion rights nonprofit, shows that most na-

\footnotetext{
77 Scalia, supra note 74, at 309 ("Adding foreign law to the box of available legal tools is enormously attractive to judges because it vastly increases the scope of their discretion. In that regard it is much like legislative history, which ordinarily contains something for everybody and can be used or not used, used in one part or in another, deemed controlling or pronounced inconclusive, depending upon the result the court wishes to reach."); see also Melissa A. Waters, Treaty Dialogue in Sanchez-Llamas: Is Chief Justice Roberts a Transnationalist, After All?, 11 LEWIS \& CLARK L. REV. 89, 91 n.8 (2007) (quoting confirmation testimony of Chief Justice Roberts: “[R]elying on foreign precedent doesn't confine judges. It doesn't limit their discretion the way relying on domestic precedent does. Domestic precedent can confine and shape the discretion of the judges. Foreign law, you can find anything you want ... [a]nd that actually expands the discretion of the judge.").

78 Waters, supra note 77, at 91 n.8 (quoting confirmation testimony of Chief Justice Roberts: "If we're relying on a decision from a German judge about what our Constitution means, no president accountable to the people appointed that judge, and no Senate accountable to the people confirmed that judge, and yet he's playing a role in shaping the law that binds the people in this country. I think that's a concern that has to be addressed."); Hon. J. Harvie Wilkinson III, The Use of International Law in Judicial Decisions, 27 HARV. J.L. \& PUB. POL'Y 423, 426 (2004) ("[W]hen judges rely on foreign sources, especially for difficult constitutional questions concerning domestic social issues, they move the bases for judicial decision-making even farther from the realm of both democratic accountability and popular acceptance.").

79 See Calabresi, supra note 74, at 1337 ("Americans are more individualistic, more religious, more patriotic, more egalitarian, and more hostile to unions and Marxism than are the people of any other advanced democracy. This positive account of the ways in which the United States truly is exceptional will call into question the practicality and wisdom of our Supreme Court imposing foreign ideas about law on us."); Hon. Diarmuid F. O'Scannlain, What Role Should Foreign Practice and Precedent Play in the Interpretation of Domestic Law?, 80 NOTRE DAME L. REV. 1893, 1907 (2005) (noting unique aspects of United States that may make reliance on foreign law inappropriate).

${ }^{80}$ Roper, 543 U.S. at 625-26 (Scalia, J., dissenting); Scalia, supra note 74, at 309 ("The Court has generally ignored modem foreign law in its abortion cases. Casey does not mention it at all; Roe discusses only modern British law (which in any event is more restrictive than what Roe held). I will become a believer in the ingenuousness (though never in the propriety) of the Court's newfound respect for the wisdom of foreign minds when it applies that wisdom in the abortion cases.").

81 Larsen, supra note 73, at 1320.
} 
tions, if they permit abortion at all, view it as an act requiring justification. ${ }^{82}$ Permissible reasons vary from nation to nation, ranging from protection of the mother's life, to her physical or mental health, to socioeconomic factors like age, economic circumstances, marital status, or number of children. ${ }^{83}$ In this regard, Roe took a minority position by international standards. Only after viability could a state require a reason (such as protection of the mother's life or health) as a condition for obtaining an abortion. ${ }^{84}$

Among the minority of nations that require no particular reason for an abortion, the great majority limit the availability of the procedure to a time period much shorter than Roe/Casey. Of the 56 countries in this more permissive category, 41 require exercise of the abortion right within 12 weeks or some shorter time period. ${ }^{85}$ While 12 weeks is the most popular cutoff point, countries have adopted other standards, including 8 weeks, 10 weeks, 90 days, 14 weeks and 18 weeks. ${ }^{86}$ If one counts Puerto Rico as part of the United States, only six nations on the list allow unrestricted abortion to the point of viability or without any specific time limitation-Canada, China, Netherlands, North Korea, United States and Vietnam. ${ }^{87}$ A seventh country, Singapore, sets a limit of 24 weeks, which approximates the current viability threshold in the United States. ${ }^{88}$

When considered in an international perspective, the viability rule puts the United States in a small subset of nations that allow abortion on demand to the point of viability or beyond. Most of the nations that join the United States in permitting such unrestricted late-term abortions make for dubious company. Communist China's efforts toward population control clash with the theory of reproductive rights underlying the Supreme Court's abortion jurisprudence, and have led to coerced abortions in parts of that country. ${ }^{89}$

\footnotetext{
82 See CTR. FOR REPROD. RIGHTS, supra note 72, at 1-2; Larsen, supra note 73, at 1320 ("[T]he vast majority of the world's countries . . . require, at a minimum, that the pregnant woman make some showing of 'good reason' to terminate a pregnancy (141 of 195).").

${ }^{83}$ CTR. FOR REPROD. RIGHTS, supra note 72, at 1-2.

${ }^{84}$ Roe v. Wade, 410 U.S. 113, 163-64 (1973) ("If the State is interested in protecting fetal life after viability, it may go so far as to proscribe abortion during that period, except when it is necessary to preserve the life or health of the mother.").

${ }^{85}$ CTR. FOR REPROD. Rights, supra note 72 , at 2 . While Puerto Rico is listed by the Center as a separate country, its law on this point is controlled by U.S. standards. See id.

${ }^{86} \mathrm{Id}$.

87 Id.

${ }^{88}$ Id.; see Planned Parenthood of Se. Pa. v. Casey, 505 U.S. 833, 860 (1992).

${ }^{89}$ See U.S. Dep't. of State, Background Note: China (Oct. 2008), http://www.state.gov/r/pa/ei/bgn/ 18902.htm ("China's 2002 Population and Family Planning Law and policy permit one child per family, with allowance for a second child under certain circumstances, especially in rural areas, and with guidelines looser for ethnic minorities with small populations. Enforcement varies, and relies largely on 'social compensation fees' to discourage extra births. Official government policy opposes forced abortion or sterilization, but in some localities there are instances of forced abortion."); see also Zhu v. Gonzales, 493 F.3d 588, 601-02 (5th Cir. 2007) (immigrant compelled to have abortion in China entitled to with-
} 
With respect to the other two Communist regimes on the list, Vietnam also places legal limits on family size,$^{90}$ and North Korea is not viewed as a leader in human rights. ${ }^{91}$ The medical culture of the Netherlands appears to be generally less protective of fetal life than other nations, quite apart from the abortion issue. For instance, doctors in that country are much less willing than their European neighbors to provide life sustaining treatment to premature but potentially viable infants. ${ }^{92}$ Canada might seem a more conventional companion for the United States on legal questions. However, the current absence of an abortion law in Canada may be less a reflection of national sentiment than a result of Parliament's failure in attempts to enact a statute meeting standards imposed by the Canadian judiciary. ${ }^{93}$

The observation that the viability rule is an outlier from an international perspective bears out Justice Scalia's critique of the Court for selective resort to foreign practice. No obvious rationale appears for relying on foreign law in some substantive due process cases, but declining to do so in the abortion context. If the Court intends to consult foreign law in resolv-

holding of removal from U.S.); Chinese Riot Over Steps to Control Population, INT'L HERALD TRIB., May 22, 2007, at 4 (" $[\mathrm{A}]$ ccording to villagers and witness accounts posted on the Internet, officials in several parts of Guangxi mobilized their largest effort in years to roll back population growth by instituting mandatory health checks for women and forcing pregnant women who did not have approval to give birth to abort fetuses.").

90 Why Baby Boys are More Sought After in Asian Societies, STRAITs TIMEs (SINGAPORE), July 14, 2007 (Vietnam pursues a two-child per family policy); Rep. Christopher Smith, UNcertain Problem: United States Pays the U.N. Too Much, WASH. TIMES, Oct. 21, 1999, at A23 (criticizing UN support for "coercive population control systems in China and Vietnam"); David Lamb, World Perspective: Asia, L.A. TIMES, Apr. 11, 1998, at 2 (though abortion is officially discouraged in Vietnam, it is "the most common way to meet the Communist government's goal of limiting each family to two children").

91 Choe Sang-Hun, Brutally Shaped by North Korean Gulag, INT'L HERALD TRIB., July 10, 2007, at 2 (describing experiences of refugee who grew up in North Korean prison camp); North Korea: Expect Worse, THE ECONOMIST, June 23, 2007, at 52 (evidence of human rights abuses in North Korea; "over the years an estimated 500,000 to $1 \mathrm{~m}$ have been executed or have died from ill-treatment in Mr. Kim's gulag").

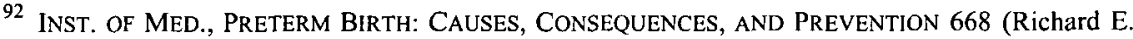
Behrman \& Adrienne Stith Butler eds., 2007) ("[I]nfants at the border of viability (those born at less than 26 weeks gestation) are resuscitated much less frequently in the Netherlands than in other European countries and the United States."); id. at 661 (European questionnaire concerning hypothetical fetus at 24-weeks gestation found that " 82 to 98 percent of physicians would resuscitate an infant in all countries studied except the Netherlands, where only 39 percent of the physicians surveyed would resuscitate the infant").

93 Margaret Somerville, Issues in the Public Square: Principles vs. Packages, 32 J.L. MED. \& ETHICS 731, 734-35 (2004) ("Parliament unsuccessfully attempted to enact an abortion law complying with the Supreme Court's ruling, leaving Canada in the unique position, among comparable countries, of having no legislation goveming abortion. It is legal until immediately before a woman goes into laborat that point, another Criminal Code provision, that is the successor to the longstanding prohibition of killing a child in the act of birth, kicks in."); Most Canadians Want Restrictions on Abortion, but Liberals Unlikely to Introduce Legislation, CATH. NEW TIMES, Nov. 21, 2004, at 6 (reporting poll results indicating 57 percent of Canadians want life protected after first three months of pregnancy). 
ing substantive due process claims, it should employ a disciplined approach that curbs judicial discretion. ${ }^{94}$

In any event, one may be skeptical of according precedential "weight" to foreign authority in interpreting the U.S. Constitution ${ }^{95}$ and nevertheless recognize legitimate reasons to examine foreign law in constitutional cases. John McGinnis argues that the Supreme Court should not view foreign precedents as authoritative, but he acknowledges that "foreign law could have informational value in that it could contain principles that the Court could embrace on the basis of some other authority." ${ }^{96}$ Other scholars point to the potential value of foreign experience in providing relevant empirical data about the consequences of particular legal rules. ${ }^{97}$ In Washington $v$. Glucksberg, for example, the Court appropriately took account of the Dutch experience with assisted suicide in finding a reasonable basis for Washington's decision to ban the practice. ${ }^{98}$

Consideration of international standards underscores the need for the U.S. Supreme Court to justify the viability rule in constitutional terms. Comparative examination reveals that countries employ a wide range of standards to govern the duration of abortion rights. This variability shows that the viability rule cannot be defended as a practical necessity, somehow indispensable for an abortion rights regime. Moreover, the Court's choice of the viability rule seems extreme in the spotlight of international practice. Of all the lines the Court could have drawn, it selected a rule far from the median generated by the legal and political systems of the world.

Recognizing that a choice has been made naturally raises the question of why the Court selected the line it did. The fact that the choice was extreme gives the question more urgency. Was the Court merely engaged in the apolitical elucidation of constitutional principles, or was there a political or social agenda at work in the selection? Comparative analysis thus interplays with the questions of legitimacy the Court raised in Casey. Even for those who support abortion rights, the fact that the viability rule permits un-

94 See Ramsey, supra note 74, at 69-70 (suggesting four guidelines for "developing a rigorous discipline for the use of international materials" to avoid a selective reliance critique).

95 See McGinnis, supra note 74, at 308 ("My position is that the use of a proposition of international law or foreign law as a gloss on the interpretation of our Constitution is objectionable only if that proposition has real authority by virtue of its intemational or foreign law status. A proposition has such authority only if it has weight in the sense that the case could have come out differently in the absence of the existence of the proposition of international or foreign law, and if the authority of the proposition derives directly from its position in international or foreign law."). For a number of reasons, including those listed above, I am dubious that foreign legal materials should carry precedential force in constitutional interpretation. Therefore, I am not arguing here that the Court should view international standards as authoritative in determining the scope or duration of abortion rights in this country.

96 Id. at 310.

${ }^{97}$ See Bodansky, supra note 74 , at 425 ; Jackson, supra note 74 , at 116 ; Ramsey, supra note 74 , at 75.

98521 U.S. 702, 734-35 (1997). 
restricted abortion approximately twice as far into pregnancy as the most common international cutoff may raise a question mark about the underpinnings of the Court's jurisprudence. It becomes that much more important, therefore, that the Court disclose the constitutional analysis supporting the line it chose. Part II considers what the Court has offered to date by way of explanations for the viability rule.

\section{THE SUPREME COURT'S FAILURE TO JUSTIFY THE VIABILITY RULE}

The scope of state regulatory authority over abortion raises questions of state power and fetal entitlement. What value may the state constitutionally attribute to the developing fetus? Roe concluded that state abortion regulations may not treat a recently conceived human being as equivalent in worth to a newborn infant. ${ }^{99}$ The Roe Court did recognize a state interest in "protecting the potentiality of human life," an interest that increased in strength as the pregnancy progressed. ${ }^{100}$ But this interest in protecting fetal life did not become sufficiently "compelling" to permit prohibition of abortion until the fetus reached viability. ${ }^{101}$

Casey concluded that the cases following Roe had not fully appreciated the state's legitimate interest in fetal life. ${ }^{102}$ The state, accordingly, could recognize ample value in the previable fetus to support regulations designed to promote reflection, such as waiting periods and informed consent laws. ${ }^{103}$ But the Casey plurality continued to see viability as the point at which a state may deem the fetus of sufficient worth or dignity to warrant prohibition of abortion. ${ }^{104}$

The authors of Casey presumably believed that the viability rule satisfied the requirements for judicial legitimacy set forth in their opinion. Attentive reading of the Court's decisions, however, demonstrates that the Court has never provided a principled justification for the viability rule. In seeking to explain adherence to the rule, the Casey authors first pointed readers to the opinion in $R o e,{ }^{105}$ overlooking what scholars from a wide variety of backgrounds have recognized: Roe literally provided no argument in favor of treating viability as the controlling line, much less an argument grounded in constitutional principles. ${ }^{106}$ The legitimacy of the viability rule

\footnotetext{
${ }^{99}$ Roe v. Wade, 410 U.S. 113, 159 (1973) (Texas claimed that life begins at conception); id. at 162 (state cannot adopt a theory of life overriding a woman's right to an abortion).

100 Id. at $162-63$.

101 Id. at 163-64.

102 Planned Parenthood of Se. Pa. v. Casey, 505 U.S. 833, 873, 875 (1992) (plurality opinion).

${ }^{103} \mathrm{Id}$. at $881-87$ (upholding informed consent and waiting period provisions).

$104 \mathrm{Id}$. at 870.

$105 \mathrm{Id}$.

106 See infra notes 114-125 and accompanying text.
} 
therefore turns on Casey's own account of the significance of fetal viability, an account properly described as "conclusory."107 The discussion below shows that neither Roe nor Casey satisfied the Court's obligation to provide a principled constitutional explanation for the viability rule, and that Gonzales further complicates the search for any such justification for the Court's jurisprudence.

\section{A. The Missing Syllogism of Roe v. Wade}

Roe $v$. Wade recognized two distinct state interests that might justify regulation of abortion procedures: "[1] preserving and protecting the health of the pregnant woman ... and ... [2] protecting the potentiality of human life." 108 The Court stated that "[e]ach [interest] grows in substantiality as the woman approaches term and, at a point during pregnancy, each becomes "compelling.", 109 The state interest in maternal health becomes compelling at the end of the first trimester, the Court concluded, because "until the end of the first trimester mortality in abortion may be less than mortality in normal childbirth." 110 The Court's adoption of the viability rule appeared in its discussion of the second recognized state interest, the protection of "potential" life:

With respect to the State's important and legitimate interest in potential life, the "compelling" point is at viability. This is so because the fetus then presumably has the capability of meaningful life outside the mother's womb. State regulation protective of fetal life after viability thus has both logical and biological justifications. ${ }^{111}$

The conclusion that the state interest in fetal life became compelling at viability meant that a state could proscribe abortion after that point "except when it is necessary to preserve the life or health of the mother."112

Despite profound divisions over the constitutional status of abortion rights, ${ }^{113}$ there is broad academic agreement that $R o e$ failed to provide an

107 See Casey, 505 U.S. at 989 n.5 (Scalia, J., concurring in the judgment in part and dissenting in part) (describing plurality's defense of viability rule as "conclusory").

108410 U.S. 113,162 (1973).

${ }^{109}$ Id. at $162-63$.

${ }^{110}$ Id. at 163 .

111 Id. One should distinguish the question of when a state may regulate to protect fetal life from the separate question of when the Constitution itself protects human life. Roe concluded that a fetus did not qualify as a "person" for Fourteenth Amendment purposes, and therefore did not possess a constitutionally conferred right to life. $l d$. at 156-59.

${ }^{112}$ Id. at $163-64$.

113 See John Copeland Nagle, Choosing the Judges Who Choose the President, 30 CAP. U. L. REv. 499, 517 (2002) ("Abortion is probably the most controversial issue facing the Court . ..."); Robin West, Progressive and Conservative Constitutionalism, $88 \mathrm{MICH}$. L. REv. 641, 646 (1990) (describing Roe as "the Burger Court's most controversial decision"). 
adequate explanation for the viability rule. Shortly after release of the opinion, John Hart Ely commented that "the Court's defense seems to mistake a definition for a syllogism."114 His succinct critique "has come to summarize the scholarly consensus that the Court failed to offer a meaningful justification of its viability standard." 15 Many scholars have seconded Ely's criticism. ${ }^{116}$ Laurence Tribe observed that "[o]ne reads the Court's explanation several times before becoming convinced that nothing has inadvertently been omitted. . . . Clearly, this mistakes 'a definition for a syllogism,' and offers no reason at all for what the Court has held." 117 Christopher Eisgruber described Roe's justification for the viability rule as "blatantly circular." 118 Nancy Rhoden agreed with Ely that the Roe Court provided "nothing more than the definition of viability." 119 Even Radhika Rao, one of Justice Blackmun's former clerks, in an article celebrating his abortion opinions, described Roe's defense of the viability rule as "cryptic." ${ }^{20}$

Unpacking Ely's comment makes it possible to see more precisely the defect in Roe's defense of viability. A "syllogism," the classical form of deductive argument, ${ }^{121}$ involves two propositions - a major premise and a minor premise-that logically necessitate the syllogism's conclusion. ${ }^{122}$ One standard example purports to demonstrate the mortality of Socrates:

114 Ely, supra note 18, at 924.

115 David M. Smolin, The Religious Root and Branch of Anti-Abortion Lawlessness, 47 BAYLOR L. REV. 119, 137 n.79 (1995).

"16 See David L. Faigman, "Normative Constitutional Fact-Finding": Exploring the Empirical Component of Constitutional Interpretation, 139 U. PA. L. REV. 541, 575 (1991) (quoting Ely, supra note 18, at 924); Linton, supra note 56, at 39 n. 108 (same); Gregory J. Roden, Roe v. Wade and the Common Law: Denying the Blessings of Liberty to Our Posterity, 35 UWLA L. REv. 212, 269 n.219 (2002-2003) (same); Tom Stacy, Death, Privacy and the Free Exercise of Religion, 77 CORNELL L. REV. 490, 510 n.68 (1992) (quoting Ely but defending the viability rule on a ground not offered by the Roe Court); Lynn D. Wardle, "Time Enough": Webster v. Reproductive Health Services and the Prudent Pace of Justice, 41 FLA. L. REV. 881,911 n.178 (1989) (quoting Ely); Mark J. Beutler, Note, Abortion and the Viability Standard-Toward a More Reasoned Determination of the State's Countervailing Interest in Protecting Prenatal Life, 21 SETON HALL L. REV. 347, 359 n.71 (1991) (quoting Ely and noting that "[ $\mathrm{t}]$ he Court's rationale for this distinction is simply inadequate").

117 Laurence H. Tribe, Foreward: Toward a Model of Roles in the Due Process of Life and Law, 87 HARV. L. REV. 1, 4 (1973) (quoting Ely, supra note 18, at 924).

118 Christopher L. Eisgruber, The Fourteenth Amendment's Constitution, 69 S. CAL. L. REV. 47, 96 \& n.171 (1995).

119 Rhoden, supra note 3, at 664.

120 Radhika Rao, The Author of Roe, 26 HASTINGS CONST. L.Q. 21, 30 (1998). Professor Rao goes on to argue that "Justice Blackmun struck a brilliant and ingenious compromise by drawing the line at viability, an intermediate stage in the course of pregnancy that correlates with a phase of fetal development thought to be critical from the standpoint of several different theories." Id. at 33-34.

121 Ruggero J. Aldisert, Perspective from the Bench on the Value of Clinical Appellate Training of Law Students, 75 MISS. L.J. 645, 665 (2006).

122 ANDREW H. BACHHUBER, S.J., INTRODUCTION TO LOGIC 87 (1957); JOSEPH GERARD BRENNAN, A HaNDBOOK OF Logic 45 (2d ed. 1957); AlbuREy CaStell, A COLlege LogiC 112 (1935); F.C.S. SCHILlER, FORMAL LOGIC: A SCIENTIFIC AND SOCIAL PROBLEM 179 (1912). 
Major Premise: All men are mortal.

Minor Premise: Socrates is a man.

Conclusion: Socrates is mortal. ${ }^{123}$

The conclusion of a properly constructed syllogism may be either true or false, depending on whether the major and minor premises are both accurate. It could be, for instance, that the major premise in this example is false because not all men are mortal. Or the minor premise might be subject to challenge on the ground that Socrates is not properly classified as a man. In either case, one might escape the conclusion that Socrates is mortal. However, if the major and minor premises are both true, the conclusion of the syllogism follows as a matter of logical necessity. ${ }^{124}$

Applying this analytical framework to Roe's discussion of the viability rule, the Court's definition of viability could supply the minor premise for a syllogism, and its ban on previability regulations protecting fetal life could constitute the conclusion:

Minor Premise: A viable fetus can survive outside the womb.

Conclusion: Only a viable fetus can be protected by the state. ${ }^{125}$

What Roe neglected to include, from this perspective, was the major premise of the argument. The Court failed to offer any constitutional principle connecting state regulatory power and the value of developing fetal life that - when combined with the Court's definition of viability-would entail the conclusion that the state can only prohibit abortion of a viable fetus. Section B considers whether Casey supplied the constitutional premise missing from the argument in Roe.

123 CASTELL, supra note 122, at 112 (substituting "Greeks" for "Socrates"); see also HARRY J. GENSLER, LOGIC: ANALYZING AND APPRAISING ARGUMENTS 3 (1989) (setting forth a form of these premises to see if the reader can identify the appropriate conclusion).

124 BACHHUBER, supra note 122, at 87 (in a syllogism "the conclusion . . . is so related to the premises taken jointly that if they are true, it must also be true"); BRENNAN, supra note 122, at 45 ("The syllogism is a form of deductive argument in which, granting the truth of two statements (called the premises), the truth of a third statement (the conclusion) necessarily follows.").

${ }^{125}$ See SCHILLER, supra note 122 , at 180 ("The minor term is the subject in the conclusion, the major the predicate."). 


\section{B. The Ambiguous and Conclusory Syllogism of Planned Parenthood v. Casey}

Though it rejected Roe's "trimester framework," Casey retained the viability rule because the authors believed that liberty required a "line that is clear" to govern abortion rights. ${ }^{126}$ The value of a judicially developed uniform line seems debatable in this context. Having reaffirmed the right to terminate a pregnancy "in its early stages," ply made duration one factor in a court's analysis of whether a particular legislative scheme places an "undue burden" on abortion rights. ${ }^{128}$ This approach would have left the initial line-drawing task to legislative bodies, with courts evaluating the rules they drafted.

In any event, if one seeks a clear line in pregnancy, viability is an unlikely choice. Viability generates disagreement among medical professionals because it involves predictions made on a case-by-case basis after consideration of multiple factors, including probabilities that shift over time. ${ }^{129}$ Casey could have achieved much greater clarity with a rule focused on gestational age (e.g., 8 weeks or 12 weeks) or some less debatable milestone in the process of fetal development. ${ }^{130}$

The decision to reaffirm the viability rule provided the authors of $\mathrm{Ca}$ sey a new opportunity to furnish the constitutional rationale neglected by Roe. Two paragraphs in the Casey opinion explain the reasons for retention of viability as the controlling line. Consideration of each in turn shows that the plurality opinion fell short of its goal; nothing in either paragraph sets forth a nonarbitrary constitutional justification for the viability rule.

Casey's first paragraph defending the viability rule rested on stare decisis and invoked the Court's discussion in Roe: "Any judicial act of linedrawing may seem somewhat arbitrary, but Roe was a reasoned statement, elaborated with great care." ${ }^{131}$ However one evaluates the Casey plurality's

26 Planned Parenthood of Se. Pa. v. Casey, 505 U.S. 833, 869 (1992) (plurality opinion).

127 Id. at $844,846$.

${ }^{128} \mathrm{Id}$. at 876 ("The very notion that the State has a substantial interest in potential life leads to the conclusion that not all regulations must be deemed unwarranted. Not all burdens on the right to decide whether to terminate a pregnancy will be undue. In our view, the undue burden standard is the appropriate means of reconciling the State's interest with the woman's constitutionally protected liberty.").

129 See supra notes 61-65 and accompanying text; see also Linton, supra note 56, at 40-41 (noting factors that can influence assessments of viability).

130 See Linton, supra note 56, at 41 (noting that the Roe Court could have selected a more workable line than viability by simply choosing a particular gestational age); Wardle, supra note 116, at $912 \mathrm{n} .182$ (suggesting that viability may not be an easy standard to apply).

131 Casey, 505 U.S. at 870 (plurality opinion). The entire paragraph invoking stare decisis in support of the viability rule reads as follows:

We conclude the line should be drawn at viability, so that before that time the woman has a right to choose to terminate her pregnancy. We adhere to this principle for two reasons. First, as we have said, is the doctrine of stare decisis. Any judicial act of line-drawing may seem somewhat arbitrary, but Roe was a reasoned statement, elaborated with great care. We have twice reaffirmed 
application of stare decisis, ${ }^{132}$ this portion of the opinion cannot supply the justification for the viability rule that Roe omitted. The plurality's description of Roe as "a reasoned statement, elaborated with great care" overlooks the fact that Roe did not offer a reason for treating viability as the controlling line for constitutional purposes. ${ }^{133}$

Beyond the initial paragraph relying on stare decisis, the Casey plurality included a second paragraph setting forth three arguments to explain the Court's continued focus on fetal viability. To facilitate discussion, I have numbered the arguments and omitted extraneous material:

[1] The second reason [we adhere to the viability rule] is that the concept of viability, as we noted in Roe, is the time at which there is a realistic possibility of maintaining and nourishing a life outside the womb, so that the independent existence of the second life can in reason and all fairness be the object of state protection that now overrides the rights of the woman.

[2] We must justify the lines we draw. And there is no line other than viability which is more workable.

[3] The viability line also has, as a practical matter, an element of faimess. In some broad sense it might be said that a woman who fails to act before viability has consented to the State's intervention on behalf of the developing child. ${ }^{134}$

These three arguments represent the totality of Casey's contribution to Roe's defense of the viability rule.

Recalling Casey's criteria for judicial legitimacy, it quickly becomes apparent that the latter two of these three arguments cannot count toward establishing the necessary principled constitutional justification for the viability rule. A majority of the Justices in Casey recognized the Court's obligation to "speak and act in ways that allow people to accept its decisions . . . as grounded truly in principle, not as compromises with social and politi-

it in the face of great opposition. Although we must overrule those parts of Thomburgh and Akron $I$ which, in our view, are inconsistent with Roe's statement that the State has a legitimate interest in promoting the life or potential life of the unborn, the central premise of those cases represents an unbroken commitment by this Court to the essential holding of Roe. It is that premise which we reaffirm today. Id.

132 It has never been apparent to me why one must understand the "essential holding" of Roe to include the viability rule, rather than Roe's more basic conclusion that the Constitution protects "a woman's decision whether or not to terminate her pregnancy." Roe v. Wade, 410 U.S. 113, 153 (1973). It is also not clear why stare decisis permits abandonment of Roe's trimester framework, but supports retention of the viability rule, one of the cornerstones of that framework. See Beck, supra note 6, at 719-20.

${ }^{133}$ See supra notes 114-125 and accompanying text.

${ }^{134}$ Casey, 505 U.S. at 870 (plurality opinion) (emphasis added). 
cal pressures."135 The Court's justification must show the warrant for the ruling in the Constitution and must be "sufficiently plausible to be accepted by the Nation."136 In light of these standards, the plurality's assertion that no other line is "more workable" than viability, if it were true, ${ }^{137}$ might contribute to an argument for adopting viability as an arbitrary compromise. But it does not supply a principled defense of the viability rule grounded in the Constitution. Likewise, though one may plausibly view delay in obtaining an abortion as implied consent to state regulation, the plurality offered no reason to select viability as the point at which to presume consent. The same argument could be made in favor of drawing the line at the end of the first trimester, at quickening, or at many other points in pregnancy. ${ }^{138}$

We are left, then, with the first argument from the quoted paragraph: the plurality's contention that viability marks "the independent existence of [a] second life" that the state may protect notwithstanding the constitutional claims of the mother. David Smolin suggests that the Casey plurality here falls into the same error as the Court in Roe, mistaking the definition of viability for a syllogism. ${ }^{139}$ This critique carries considerable force. The phrase "independent existence of [a] second life" could simply be the plurality's way of rephrasing the definition of "viability," in which event $\mathrm{Ca}$ sey offers nothing to justify the viability rule beyond what the Court provided in Roe.

However, for the sake of discussion, we will assume that a generous reader could understand the Casey plurality to imply a syllogism in the following form:

Major Premise: The state may protect a fetus against abortion only when the fetus constitutes a "second life" with an existence "independent" of the mother.

Minor Premise: The fetus becomes a second life with an independent existence at viability, when there is a possibility of maintaining and nourishing life outside the womb.

\footnotetext{
${ }^{135} I d$ at $865-66$.

${ }^{136} I d$. at 866; see supra notes $31-47$ and accompanying text.

137 David Smolin suggests that "[f]ertilization would appear more workable than viability." Smolin, supra note 115 , at 137 n.82. A fertilization rule would certainly be easier to apply. Likewise, a line based on any easily determined milestone in fetal development would remove much of the guesswork inherent in the viability rule. See supra text accompanying note 130. In any event, this argument gives no reason for adopting viability over other lines that would be at least equally workable.

138 Smolin, supra note 115 , at $137 \mathrm{n} .82$ ("This perhaps explains why the line can be drawn earlier than birth, but utterly fails to explain why the State cannot prohibit previability abortions.").

139 Id. ("Stating the definition of viability as a defense of the viability standard has long been ridiculed by even pro-choice commentators.").
} 
Conclusion: Only a viable fetus may receive state protection from abortion.

Framing the syllogism in this fashion allows us to consider whether a requirement of a second life with an independent existence could serve as a constitutional principle justifying the Court's selection of viability as the controlling line.

The initial problem with the suggested syllogism concerns the ambiguous language of the major premise. The terms "second life" and "independent existence" in Casey could mean at least two quite different things, depending on whether the plurality envisioned a purely biological concept, or rather a particular sort of "life" or degree of "independence" thought to carry moral or legal significance. If we understand the terms in a purely biological sense, there may be something to the idea that courts should deem a "second life" with "independent existence" a necessary condition for state protection. Applying common law principles and Article III justiciability requirements, courts have long understood that one cannot sue oneself. $^{140}$ This principle could conceivably imply a corresponding limitation on legislative power, making it inappropriate for a state to invest an individual's body parts with distinct legal interests, separate from those of the individual herself. ${ }^{141}$

But if this is all Casey meant by a "second life" with "independent existence"- that two distinct biological organisms must exist before the state may protect one against the other-then the major premise of the Casey syllogism seems relatively trivial. More importantly, on this reading of $\mathrm{Ca}$ sey's language, the minor premise is patently false. No one can reasonably doubt that a developing fetus constitutes a living biological organism distinct from its mother long before the point of viability. Indeed, recognition of the biological distinction between the mother and the fetus would appear to underlie the Casey plurality's conclusion that the state has a legitimate interest in unborn human life from the outset of the pregnancy. ${ }^{142}$

\footnotetext{
140 S. Spring Hill Gold Mining Co. v. Amador Medean Gold Mining Co., 145 U.S. 300, 301 (1892) (the requirement of adverse parties is no longer satisfied where corporate litigants are under common ownership); Lee Publ'ns, Inc. v. Dickinson Sch. of Law, 848 A.2d 178, 188 (Pa. Commw. Ct. 2004) ("It is a common principle of law that one cannot sue oneself."), appeal dismissed, 857 A.2d 675 (Pa. 2004); Michael Herz, United States v. United States: When Can the Federal Government Sue Itself?, 32 WM. \& MARY L. REV. 893, 894-95 (1991) ("However divided you may be, you may not, in general, sue yourself. ... That a lawsuit, by definition, requires at least two parties has always been clear to common law courts. Federal courts have found the same principle in the Constitution's case-or-controversy requirement.").

141 It would be strange, for example, if a state could authorize a claim by a person's right hand against his left, or a suit against a smoker pursued in the name of his cardiopulmonary system.

142 Planned Parenthood of Se. Pa. v. Casey, 505 U.S. 833, 846 (1992) ("[T] he State has legitimate interests from the outset of the pregnancy in protecting the health of the woman and the life of the fetus that may become a child.").
} 
A second possible reading of Casey understands the plurality to be referencing some legal or moral concept of what constitutes a second "life" with an "independent existence" worthy of protection by the state. At this point, though, the joint opinion leaves the reader to his own devices. Nothing in Casey conveys precisely what the plurality meant by a second life with an independent existence (assuming, by hypothesis, that the terms do not simply rephrase the definition of viability). Nor does the opinion explain how these concepts relate to state regulatory power or the manner in which the plurality derived these requirements from the Constitution.

Consider the critical questions Casey leaves unaddressed. First, why should dependence on another disqualify someone from state protection? In fields such as prisoners' rights, parent-child relationships, and the rights of comatose patients, the fact of dependence is thought to create legal interests, not eliminate them. ${ }^{143}$ Of course, pregnancy involves a unique form of dependence, but Justice Kennedy recognized in his Stenberg dissent that the state interest in protecting dependent human life applies likewise to the life of a fetus. ${ }^{144}$ Second, if "independence" matters, why insist on the particular form of hypothetical independence associated with viability? In other contexts, the law has conferred legal protection on the unborn at earlier stages of pregnancy, based on either genetic independence from the mother (conception) or the capacity for independent movement (quickening). ${ }^{145}$ Third, how does this independent existence requirement flow from the Con-

\footnotetext{
143 Beck, supra note 6 , at 729.

144 Stenberg v. Carhart, 530 U.S. 914, 962 (2000) (Kennedy, J., dissenting) ("A State may take
} measures to ensure the medical profession and its members are viewed as healers, sustained by a compassionate and rigorous ethic and cognizant of the dignity and value of human life, even life which cannot survive without the assistance of others." (citing Washington v. Glucksberg, 521 U.S. 702, 730-34 (1997))).

145 Some jurisdictions include the unborn within their homicide statutes from the point of conception. See Philip G. Peters, Jr., The Ambiguous Meaning of Human Conception, 40 U.C. DAVIS L. REV. 199, 200 (2006) ("Many states criminalize the killing of early embryos with feticide or fetal homicide statutes."); id. at 203-04 (suggesting that such statutes contain an ambiguity because "conception" is actually a multi-stage process that takes place over time). A few permit wrongful death claims based on negligent injury to a previable fetus. See John M. Breen \& Michael A. Scaperlanda, Never Get Out' $a$ the Boat: Stenberg v. Carhart and the Future of American Law, 39 CONN. L. REV. 297, 317-18 \& n.92 (2006); Dena M. Marks, Person v. Potential: Judicial Struggles to Decide Claims Arising from the Death of an Embryo or Fetus and Michigan's Struggle to Settle the Question, 37 AKRON L. REV. 41, 71-74 (2004). A conceived but unborn heir has long been entitled to inherit from a decedent's estate so long as the heir is subsequently born alive. Roe v. Wade, 410 U.S. 113, 162 (1973). The common law attached significance to the point of fetal "quickening"-_."the first recognizable movement of the fetus in utero," id. at 132, 134, which typically occurs between 16 and 20 weeks, several weeks before viability. Kirsten Rabe Smolensky, Defining Life From the Perspective of Death: An Introduction to the Forced Symmetry Approach, 2006 U. CHI. LEGAL F. 41, 72 n.158 (2006) (quoting FrANK A. MANNING, FETAL MEDICINE: PRINCIPLES \& PRACTICE 46 (1995)). Georgia law requires "quickening" for a wrongful death action, but defines quickening in terms of the ability of the fetus to move its limbs, rather than requiring maternal perception of movement. See Citron v. Ghaffari, 542 S.E.2d 555, 557 (Ga. App. 2000); Smolensky, supra, at 74. See generally Wardle, supra note 116, at 912 n.181. 
stitution? Casey, like Roe, fails to offer any constitutional principle interrelating state power and fetal entitlement in a way that would justify the Court's continued adherence to the viability rule. ${ }^{146}$ Ultimately, all Casey adds to the silence of Roe is an ambiguous phrase-_ "independent existence of the second life"-released into our legal discourse without any hint of its constitutional parentage.

This analysis of Roe and Casey has shown that neither opinion offered a principled justification for the viability rule that demonstrated the constitutional warrant for treating viability as the controlling line in fetal development. It becomes increasingly difficult therefore to avoid the judgment of the Casey majority: "[A] decision without principled justification [is] no judicial act at all." 147 At the very least, the Court has fallen short of its obligation to act transparently and explain its rulings in a way calculated to convince the public of their constitutional legitimacy. Based on the reasoning of Casey, the Court has a duty to provide a constitutional justification for the viability rule or to jettison the rule as an arbitrary compromise, properly within the legislative, rather than the judicial, sphere. ${ }^{148}$

\section{Justifying the Viability Rule After Gonzales v. Carhart}

The viability rule played a significant role in the Court's most recent abortion decision. In Gonzales $v$. Carhart, the Court rejected a facial challenge to the Partial-Birth Abortion Ban Act of 2003, ${ }^{149}$ a federal statute prohibiting intact $D \& E$ abortions, where a physician partially delivers a living fetus before causing its death. ${ }^{150}$ The Court addressed several issues in Gonzales that are tangential to our discussion, ${ }^{151}$ but in a particularly relevant section of the opinion, the Court considered whether the act violated the viability rule on the ground that it was designed to create "a substantial obstacle to late-term, but previability, abortions." 152

\footnotetext{
146 Faigman, supra note 116, at 575 ("The juncture of viability does not have independent constitutional significance, at least insofar as it lacks an explicit constitutional value to support it.").

147 Casey, 505 U.S. at 865.

148 See supra notes $31-47$ and accompanying text.

149 127 S. Ct. 1610,1619 (2007).

${ }^{150}$ Id. at 1627-28 (analyzing 18 U.S.C. $\$ 1531$ ); id. at 1629 (concluding statute applied to intact $\mathrm{D} \& \mathrm{E}$ procedure).

151 The Court rejected claims that the statute was unconstitutionally vague or overbroad, id. at 1627-32 (distinguishing Stenberg v. Carhart, 530 U.S. 914 (2000)), held that the absence of a health exception did not invalidate the legislation, $i d$. at 1635-38, and indicated that the statute should have been challenged as applied rather than on its face, id. at 1638-39.

${ }^{152} \mathrm{Id}$, at 1632 . Section IV of the opinion assumed that the viability rule applied and that the act "would be unconstitutional "if its purpose or effect is to place a substantial obstacle in the path of a woman seeking an abortion before the fetus attains viability."' Id. (quoting Casey, 505 U.S. at 878 (plurality opinion)). In section IV.A, the Court considered the legislative purpose behind the enactment. Id. at 1632-35. In section IV.B, the Court considered whether the statute had an impermissible effect due to the absence of a health exception. Id. at 1635-38.
} 
The Court concluded that the statute served legitimate governmental purposes. ${ }^{153}$ The legislation expressed respect for the dignity of human life in the face of what Congress described as a "brutal and inhumane procedure."154 It safeguarded the integrity and reputation of the medical profession, preventing doctors from participating in a procedure that involves delivering all but the head of an unborn child for the purpose of taking its life. ${ }^{15 s}$ Significantly, the Court also approved Congress's desire to erect a barrier against infanticide. The majority quoted a congressional finding that the intact D\&E procedure has a "disturbing similarity to the killing of a newborn infant,"156 and highlighted the legislative goal of "draw[ing] a bright line that clearly distinguishes abortion and infanticide."157

The statute at issue in Gonzales placed no restriction on abortions performed using the standard D\&E procedure. ${ }^{158}$ The legislation therefore did not prevent abortion of a previable fetus, but merely prohibited one procedure by which a previability abortion might be carried out. The dissenting Justices saw little basis for distinguishing between the intact D\&E procedure prohibited by the statute and the standard (nonintact) D\&E procedure that remained unregulated:

Nonintact D \& E could equally be characterized as "brutal," involving as it does "tear[ing] [a fetus] apart" and "ripp[ing] off" its limbs. "[T] he notion that either of these two equally gruesome procedures ... is more akin to infanticide than the other, or that the State furthers any legitimate interest by banning one but not the other, is simply irrational."159

The majority believed, however, that Congress could rationally view the intact $D \& E$ procedure as raising concerns not presented by a standard $D \& E$ abortion, since the former involves partial delivery of the fetus and "perverts a process during which life is brought into the world." 160

This Essay has focused on the Court's failure to offer a constitutional justification for the viability rule. It may be, as several Justices have suggested, that the viability line is entirely arbitrary from a constitutional perspective. ${ }^{161}$ Perhaps there is no constitutionally relevant distinction between a viable fetus and a previable fetus that requires the state to treat them differently. My claim in this section of the Essay, however, is less ambitious.

${ }^{153} \mathrm{Id}$. at $1632-35$.

$154 I d$. at 1632-33 (discussing congressional finding 14(N)).

155 Id. at 1633 (discussing congressional finding 14(J)).

${ }^{156} I d$. (quoting congressional finding 14(L)).

157 Id. at 1633-34 (quoting congressional finding $14(\mathrm{G})$ ).

158 Id. at 1634-35.

${ }^{159}$ Id. at 1647 (Ginsburg, J., dissenting) (quoting Stenberg v. Carhart, 530 U.S. 914, 946-47 (2000) (Stevens, J., concurring)).

${ }^{160} I d$. at 1634-35 (majority opinion) (quoting congressional finding 14(K)).

161 See supra notes $6,7,11$ and accompanying text. 
I seek to show only that the Gonzales opinion makes it more difficult to flesh out and defend a principled constitutional justification for the viability rule along the lines alluded to in Casey. I am not arguing that the holding in Gonzales violates the viability standard. ${ }^{162}$ The majority carefully drafted its opinion to allow future adherence to the viability rule should the Court so choose. ${ }^{163}$ But though the outcome in Gonzales can be formally reconciled with the viability rule, it nevertheless makes that rule harder to explain. The Gonzales opinion will complicate matters considerably if the Court ever takes up the challenge of defending the viability rule in constitutional terms.

The Gonzales opinion makes it more difficult to justify the viability rule no matter which reading one adopts for Casey's statement that viability marks the "independent existence of [a] second life." 64 If one understands that phrase in a biological sense to mean that the previable fetus does not constitute a biological organism distinct from the mother, Gonzales reached the opposite conclusion. The Court upheld the application of the federal statute to a previable fetus "because, by common understanding and scientific terminology, a fetus is a living organism while within the womb, whether or not it is viable outside the womb." 165 Thus, one possible reading of Casey's attempt to justify the viability rule cannot be reconciled with Gonzales.

The other possible reading of Casey treats the phrase "independent existence of [a] second life" as referring to a legal or moral concept-the idea that only at viability does the fetus attain the kind of independence from the mother necessary to support a prohibition of abortion. ${ }^{166}$ The Gonzales opinion will complicate this argument because the Court exhibited a high level of respect for the value of a previable fetus. The Court deemed a lateterm fetus, even prior to viability, sufficiently similar to a newborn infant that partial delivery of the fetus in the abortion process could make abortion and infanticide hard to distinguish. ${ }^{167}$ Once the Court has associated the previable fetus and the newborn infant in this fashion, it becomes less plausible that the viable fetus differs in kind for constitutional purposes from the same fetus an hour, a day, or a week before viability.

The Court's conclusion that Congress can legitimately protect the previable fetus from a brutal death through the intact $D \& E$ procedure raises the

\footnotetext{
${ }^{162}$ Cf. Gonzales, 127 S. Ct. at 1641, 1649-50 (Ginsburg, J., dissenting) (criticizing majority for blurring viability rule).

163 See id. at 1626-27 (majority opinion) (noting that not all the Justices in the majority agreed with Casey, but "assuming" its principles applicable in this case).

164 Planned Parenthood of Se. Pa. v. Casey, 505 U.S. 833, 870 (1992) (plurality opinion).

165 Gonzales, 127 S. Ct. at 1627.

166 See supra text following note 142.

167 Gonzales, 127 S. Ct. at 1633-34.
} 
question why a legislature may not protect the same fetus from other brutal abortion techniques. The possible distinction the majority perceived between intact D\&E and standard D\&E abortions offers little assistance in justifying the viability rule. To say that a legislature may distinguish between the two procedures for legislative purposes does not show why it must distinguish between them on constitutional grounds. If a legislature may view the previable fetus as a being that warrants protection against the intact D\&E procedure, it should be able to protect the same fetus against the standard D\&E. The dignity of the not-quite-viable fetus does not change depending on the method by which it will be aborted.

Prior to Gonzales, if the Court sought to justify the viability rule, it would have needed to present a principled constitutional theory interrelating state power and fetal entitlement such that the state interest in protecting fetal life (a) exists at the outset of pregnancy, ${ }^{168}$ (b) grows in strength as the pregnancy progresses, ${ }^{169}$ but (c) does not become strong enough to warrant a prohibition of abortion until the precise moment that the fetus can survive outside the womb. ${ }^{170}$ In the post-Gonzales world, the task of establishing the legitimacy of the viability rule has become significantly more demanding. Now if the Court wishes to justify the viability rule in a manner consistent with its precedents, it will need an even more subtle and discriminating constitutional analysis, capable of explaining why the state may ascribe sufficient value to a previable fetus to protect it against death by one means, but may not value it sufficiently to protect it against death by other means. It must offer a principled constitutional theory interrelating state power and fetal entitlement, such that the state interest in protecting fetal life (a) exists at the outset of pregnancy, (b) grows in strength as the pregnancy progresses, (c) warrants protecting a previable fetus against an intact D\&E abortion due to the similarity of that fetus to a newborn infant, ${ }^{171}$ but nevertheless (d) does not warrant protecting the fetus from other abortion methods until it can survive outside the womb. This is the challenge the Court must meet if it wishes to show that the viability rule satisfies Casey's test of legitimate constitutional decisionmaking.

\section{CONCLUSION}

In the contentious arena of abortion rights, all of the Justices affirm the importance of judicial legitimacy. They all acknowledge that legitimacy requires the Court to offer principled justifications for its constitutional decisions. It remains to be seen, however, whether the Court will take up the largely neglected question of the justification for the viability rule, one

\footnotetext{
168 Casey, 505 U.S. at 846.

169 Roe v. Wade, 410 U.S. 113, 162-63 (1973).

170 Casey, 505 U.S. at 870 (plurality opinion).

171 Gonzales, 127 S. Ct. at 1633-34.
} 
critical component in this highly visible segment of the Court's constitutional jurisprudence. To date, the Court has failed to offer any theory showing why the Constitution prevents a legislature from protecting fetal life until the fetus can survive outside the womb. Until the Court undertakes that challenge, its work remains incomplete and a significant facet of its abortion jurisprudence falls short of the standard of legitimacy the Court set for itself in Casey. 